\title{
O herói Quaderna ajusta contas no palco
}

\author{
Mariângela Alves de Lima
}

II erdeiro do trono legítimo do Brasil, rei prometido do Quinto Império dos sebastianistas, Dom Pedro Dinis Quaderna é, além disso, o sucessor literoteatral de Macunaíma. Vivendo desde os anos setenta do século passado nas páginas dos romances de Ariano Suassuna, Quaderna era, há muito tempo, O Desejado do Centro de Pesquisa Teatral do Sesc. Agora, sob a direção de Antunes Filho, o herói paraibano erige sobre o palco o Castelo e Fortaleza de seu império sertanejo.

Baseando-se nos dois romances protagonizados por Quaderna, a adaptação assinada pelo diretor do espetáculo entra em cena com o título de A Pedra do Reino. Nos livros, todos os gêneros almejados e nomeados pelo criador do herói puderam exercitar-se em liberdade. Misturas esplêndidas da memorialística, da tragédia, da oratória barroca, da novela romântica, das narrativas de cordel, da mitologia sertaneja, do repertório da poesia romântica e até, em raros momentos, de técnicas da ficção realista, constituem uma estratégia por meio da qual o protagonista afirma a identidade do seu reino onde se mesclam todas as culturas do hemisfério ocidental. Citação, apropriação, paródia ou, inversamente, elevação do banal à categoria do sublime intercalam-se no formato "epopéico", parente próximo do folhetim e tal como seu enobrecido antecessor, gênero dotado de ganchos para cativar seus leitores por muito tempo.

Não podendo ser na mesma medida generosa "epopéico" e folhetinesco, o Quaderna apresentado no espetáculo do CPT é, antes de tudo, o memorialista. Chamado por um corregedor para prestar esclarecimentos, participa de um processo que é, no tempo sintético do teatro, um ajuste de contas feito no tribunal da consciência. Elementos circunstanciais da história do País, que nos romances de Suassuna são embelezados pelas tinturas da emoção e do mito, entram resumidos em cena, quase como legendas necessárias para esclarecer cisões ideológicas persistentes na história contemporânea. São minimizados ou excluídos da adaptação aportes sociológicos e a crônica histórica que Ariano Suassuna mobiliza para lembrar ao leitor de hoje as convulsões que o sertão e as cidades nordestinas litorâneas atravessaram desde o final do século dezenove até o golpe que instituiu o Estado Novo.

Situado no plano da memória, colocado na posição frontal de narrador, o protagonista da encenação desvencilha-se em parte da missão de caracterizar e reproduzir a imensa riqueza

Mariângela Alves de Lima é pesquisadora e crítica de teatro de O Estado de S. Paulo. 
cultural do seu cenário natal. Os cantares de todos os gêneros que a personagem recolhe (como o príncipe português de quem empresta o nome) são exemplificados de modo sucinto no espetáculo. Há contornos límpidos feitos com resquícios das cores fortes e das formas abruptas da paisagem. $\mathrm{O}$ trato visual traduz a exuberância nordestina para outra linguagem, quase abstrata, mais plástica do que dramática, expurgada dos traços barrocos da escrita original.

Sem a pretensão de mimetizar a paisagem, os tipos e conflitos da cidade e do sertão paraibanos, o espetáculo emula o procedimento dos romances ao extrair o encantamento estético do que é "bruto, despojado e pobre". Materiais submetidos a um trato artesanal, exibindo a marca das operações que os transformam em instrumentos simbólicos, são arranjados para imitar as operações do Palhaço-Rei sobre a feiúra do real. É assim, por exemplo, que as cavalgadas belicosas onde se misturam em bandos aguerridos coronéis, cangaceiros, padres, fazendeiros, vaqueiros e políticos de renome, avançam em tropel cavalgando a mais ordinária peça do mobiliário doméstico. Quem viu não poderá esquecer o sertanejo sem nome e seu rebanho comprimidos no desfiladeiro imaginário e tampouco a metamorfose dessa figura na multidão que, em todos os tempos e lugares, é obrigada a ceder passagem para as cavalgadas de poderosos.

No espetáculo, o componente lírico, o belo-horrível e as representaçôes da mitologia híbrida de Quaderna deslizam em trajetos paralelos, mais ou menos distantes do narrador, como ilustrações de uma fala ininterrupta que preenche o espaço. Como signo e sonoridade, as palavras são o fulcro na encenação. Atraem, provocam e procuram manter o espectador atrelado à oralidade emulando os cantadores e "epopeieitas" a que se refere continuamente o protagonista. A galhofa, o "riso-a-cavalo, grosseiro e macho", não encontra correspondente nas imagens que atravessam o palco. Manifesta-se no modo de narrar, na voz do intérprete, na progressiva segurança com que o depoente, engolfado pela memória emotiva, esquece os perigos do inquérito e deixa de lado etiqueta e pudor.

Ao transpor para o teatro os dois romances, Antunes Filho optou por um formato em que a personagem-autor da história se sobrepõe aos episódios que testemunha. Essa escolha é, em parte, determinada pela empatia absoluta com a perspectiva existencial que resume a finalidade do inquérito de Quaderna. Chamado a prestar contas, preparando-se para o encontro com a "Morte que se imortalizará" o herói bufão deve resumir, à guisa de defesa, o credo estético em que se alicerça a obra artística. Talvez em razão da brancura simbólica do final o espetáculo se afasta da religiosidade belicosa e insurgente de Quaderna (que associa o sertão conflagrado à Judéia) e parece encaminhar-se para a resignação ao real. A tarefa difícil de alternar o delírio criador e profético ao desencanto espiritual cabe, na encenação, ao ator incumbido de representar o narrador. Lee Thalor é um intérprete excepcional pelo fôlego digno de um cantador experiente, pela inteligência com que modula as tonalidades e intençôes do texto, sobretudo pela capacidade de revestir a personagem de maturidade atemporal. 